\title{
TRADE REGULATION: SECOND GIRGUIT FINDS SHERMAN ACT VIOLATION IN MUSIGIANS UNION'S PRICE-FIXING BUT EXEMPTS COERGED UNIONIZATION OF ORCHESTRA LEADERS
}

$T_{\text {HE Second Circuit Court of Appeals, in Carroll v. American Fed'n }}$
of Musicians, ${ }^{1}$ found that the Musicians Union violated the Sherman Act $^{2}$ by establishing the minimum price charged for certain orchestral engagements. Dissident orchestra leaders had grounded their antitrust suit on particular union by-laws which not only forced performing orchestra leaders to be union members but also imposed various ancillary restrictions upon their activities, including the regulation of price floors for orchestral engagements. ${ }^{3}$ These and similar rules were promulgated by the union as a means of effectuating and preserving its control over the diverse components of the "music product" market in New York City.4 In this market, steady engagements, which are those exceeding a week's duration, and "non-club" single engagements, which consist of recording and television appearances, are generally covered by collective bargaining contracts that classify the orchestra leader as an employee of the music purchaser. ${ }^{5}$ However, those limited performances comprising the "club-date" field are rarely covered by a collective bargaining agreement. For these events, such as weddings, parties, and so forth, the orchestra leader is an employer or independent contractor. ${ }^{B}$ Since "employer-orchestra leaders" frequently take jobs as "sidemen" (orchestra members) or sub-leaders, they may alternatively occupy the roles of both employer and employee. Regardless of their function, however, all musicians must belong to the union and are subject to its rules. The district court denied that this union control of employer activities, including the maintenance of minimum price floors, constituted a violation of the antitrust laws, finding no

1372 F.2d 155 (2d Cir. 1967).

226 Stat. 209 (1890), as amended, 15 U.S.C. $\$ \S 1,2$ (1964).

¿ Carroll v. American Fed'n of Musicians, 241 F. Supp. 865 (S.D.N.Y. 1965), aff'd in part, rev'd in part, 372 F.2d 155 (2d Cir. 1967).

'See $i d$. at 158.

8241 F. Supp. at 890,$891 ; 372$ F.2d at 158-59.

- Id. at 159. See 241 F. Supp. at 887. See generally Leiter, The Musicians and Petrillo (1953). 
evidence of a conspiracy to restrain trade between the union and member orchestra leaders. ${ }^{7}$ The trial court further held that the competition between employer leaders and employee sub-leaders constituted a labor dispute to which the Sherman Act was inapplicable. ${ }^{8}$

Labor organizations are generally exempt from the federal antitrust laws when their activity pertains to a "labor dispute" concerning "terms or conditions of employment." However, in two narrow instances, a union becomes subject to liability under the Sherman Act. ${ }^{10}$ First, as indicated by the Supreme Court in Allen Bradley Co. v. Local 3, International Bhd. of Elec. Workers, ${ }^{11}$ a labor organization forfeits its Sherman Act immunity by pursuing its objectives through an anticompetitive conspiracy with a nonlabor group. ${ }^{12}$ More recently, in UMW v. Pennington, ${ }^{13}$ the Court reaffirmed the Allen Bradley doctrine by holding that a union's imposition of anticompetitive wages upon employers outside the bargaining unit violated the antitrust laws. ${ }^{14}$ Secondly, a union may transgress these laws by unilaterally pursuing objectives insufficiently related to "terms or conditions of employment," the statutory requirement which prescribes the substance of the labor exemption..$^{15}$ However, it is unclear whether this antitrust immunity is coextensive with the protection which Congress afforded labor activity

241 F. Supp. at 891 .

${ }^{8}$ Id. at $887-89$.

${ }^{\circ}$ Clayton Act $\S 6,38$ Stat. 731 (1914), 15 U.S.C. $\S 17$ (1964); Clayton Act $\$ 20,38$ Stat. 738 (1914), 29 U.S.C. $\$ 52$ (1964); Norris-LaGuardia Act $\$ 13,47$ Stat. 73 (1932), as amended, 29 U.S.C. $\$ 113$ (1964); see United States v. Hutcheson, 312 U.S. 219, 232 34 (1941); Apex Hosiery Co. v. Leader, 310 U.S. 469, 512 (1940).

${ }^{10}$ See Cox, Labor and the Antitrust Laws: Pennington and Jewel Tea, 46 B.U.I. Rev. 317, 318-19, 325-27 (1966); Hoener, The Supreme Court and the Labor Exemption, 29 A.B.A. ANTIrRust SEction 133-37 (1965). See generally Bernhardt, The Allen Bradley Doctrine: An Accommodation of Conflicting Policies, 110 U. PA. L. REv. 1094 (1965); Cox, Labor and the Antitrust Laws, 104 U. PA. L. REv. 252 (1955); Meltzer, Labor Unions, Collective Bargaining, and the Antitrust Laws, 32 U. CEr. L. REV. 659 (1965); Winter, Collective Bargaining and Competition: The Application of Antitrust Standards to Union Activities, 73 YALE L.J. 14 (1963); Comment, 1966 DUKE L.J. 191. 11325 U.S. 797 (1945).

${ }^{12}$ Id. at 809-10; see United States v. Hutcheson, 312 U.S. 219, 234-37 (1941).

18381 U.S. 657 (1965). See generally Cox, Labor and the Antitrust Laws: Pennington and Jewel Tea, 46 B.U.L. REv. 317 (1966); Comment, 1966 DUKE L.J. 191.

14 381 U.S. at $665-68$.

${ }^{15}$ See Local 189, Amalgamated Meat Cutters v. Jewel Tea Co., 381 U.S. 676, 690 (1965); Los Angeles Meat Drivers Union v. United States, 371 U.S. 94, 98-102 (1962); United States v. Hutcheson, 312 U.S. 219, $232-36$ (1941); Hawaiian Tuna Packers, Ltd. v. International Longshoremen's Union, 72 F. Supp. 562, 566 (D. Hawaii 1947); cf. Local 24, Teamsters Union v. Oliver, 358 U.S. 283, 299-95 (1959). 
under the National Labor Relations Act. To determine the scope of this immunity, the Supreme Court has attempted to reconcile the labor and antitrust policies by sanctioning a union's anticompetitive efforts in the labor market but disapproving attempts to suppress strictly commercial competition in the product market. ${ }^{10}$ The pivotal difficulty lies in distinguishing between "commercial" and "labor" activity. In Local 189, Amalgamated Meat Cutters v. Jewel Tea Co., ${ }^{17}$ three members of a severely divided Court reasoned that a "strong argument" existed in favor of the labor exemption where union efforts are directed toward subjects of mandatory collective bargaining-"wages, hours, and conditions of employment."18 Nonetheless, their view, as expressed by Mr. Justice White, was that the "crucial determinant" of the labor exemption was whether the union's interest in the desired agreement was greater than its "impact on the product market."18 However, in the opinion of three concurring Justices, all mandatory subjects of collective bargaining, that is, any matters of "direct and overriding interest" to the union, were totally exempt from the prohibitions of the Sherman Act. ${ }^{20}$ Yet even Mr. Justice Goldberg, speaking for the latter group, agreed that union interference in strictly entrepreneurial decisions, such as pricesetting, was subject to antitrust regulation because such activity impinged directly upon competition in the product market. ${ }^{21}$ Hence, both groups seemed to agree that at some point the union's interest in a particular objective is overridden by the congressional design for free competition among employers.

The difficulty of weighing union interests against the need for commercial competition is most pronounced where an independent businessman or contractor performs the same work as unionized employees. ${ }^{22}$ The NLRA prohibits the coerced unionization of a

${ }^{18}$ Compare Funt v. Crumboch, 325 U.S. 821, 824 (1945), with Hawaiian Tuna Packers, Ltd. v. International Longshoremen's Union, supra note 15, at 566.67. See Meltzer, supra note 10, at 688; Winter, supra note 10, at 42. But see Cox, Labor and the Antitrust Laws, 104 U. PA. L. REv. 252, 267-70 (1955). See generally Winter, supra note 10.

${ }_{17}^{23} 381$ U.S. 676 (1965); Comment, 1966 DUKE L.J. 191.

18381 U.S. at 689. See Cox, Labor and the Antitrust Laws: Pennington and Jewel Tea, 46 B.U.L. REv. 317, 324-27 (1966).

10381 U.S. at 690 n.5.

so Id. at 709-12 (Goldberg, J., concurring).

"Sce id. at 732-33 (Goldberg, J., concurring).

22 See Los Angeles Meat Drivers Union v. United States, 371 U.S. 94 (1962); Local 24, Teamsters Union v. Oliver, 358 U.S. 283 (1959); Local 758, Milk Drivers' Union v. Lake Valley Farm Prods., Inc., 311 U.S. 91 (1910); Greenstein v. National Skirt \& 
truly independent contractor, 23 one who is not subject to the control of the employer. ${ }^{24}$ Yet, if the contractor actually functions as an employee by competing for union jobs, the courts have recognized that the labor organization has an interest in regulating the contractor's wages, hours, and other conditions of employment in order to prevent the erosion of union standards by nonunion labor. ${ }^{25}$ However, such regulation may also interfere directly with the product market to the extent that it allows the union to dominate firms which offer services similar to those performed by union members. ${ }^{26}$ Moreover, union control of a contractor's "employee" status may restrict his decisions as an employer in the product market. ${ }^{27}$ Prior to Jewel Tea, the Supreme Court had posited the availability of antitrust remedies to prevent union regulation of noncompeting independent contractors. In Los Angeles Meat Drivers $v$. United States, ${ }^{28}$ the Court affirmed an order cancelling the union membership of contractors who had admittedly been organized for the purpose of controlling a supply of raw material in violation of the antitrust laws. The Court held that the absence of economic rivalry between employees and contractors rendered the latter a non-labor group and their unionization a conspiracy in restraint of trade. However, this "competition" criterion for antitrust immunity does not satisfy the test advocated by Mr. Justice White in Jewel Tea, since his approach would require a specific finding that the threat which the independent businessman poses to matters of direct union interest

Sportswear Ass'n, 178 F. Supp. 681 (S.D.N.Y. 1959), appeal dismissed, 274 F.2d 430 (2d Cir. 1960); Hawaiian Tuna Packers, Ltd. v. International Longshoremen's Union, 72 F. Supp. 562 (D. Hawaii 1947); cf. United States v. Fish Smokers' Trade Council, Inc., 183 F. Supp. 227 (S.D.N.Y. 1960); United States v. Women's Sportswear Mfg. Ass'n, 336 U.S. 460 (1949); Columbia River Packers Ass'n v. Hinton, 315 U.S. 143 (1942). See generally Note, 67 YaIE L.J. 98 (1957); 24 U. Chi. L. REv. 733 (1957).

${ }^{23}$ National Labor Relations Act, $\$ 8(\mathrm{~b})(4)(A)$, added by 61 Stat. 141 (1947), amended by 73 Stat. 542,29 U.S.C. $\$ 158(\mathrm{~b})$ (4) (A) (1964); cf. Hoener, supra note 10, at 144 n.61. See also National Labor Relations Act $\$ 2(3), 61$ Stat. 137 (1947), 29 U.S.C. $\$ 152(3)$ (1964).

24 See NLRB v. Steinberg, 182 F.2d 850 (5th Cir. 1950); Meltzer, supra note 10, at 685-86; cf. Los Angeles Meat Drivers v. United States, 371 U.S. 94, 107 (1962) (Goldberg, J., concurring).

${ }^{25}$ See Los Angeles Meat Drivers Union v. United States, supra note 24, at 103 (dictum); Local 24, Teamsters Union v. Oliver, 358 U.S. 283, 393-94 (1959); Local 753, Milk Drivers' Union v. Lake Valley Farm Prods., Inc., 311 U.S. 91, 98-99 (1940); Hoener, supra note 10, at 144 n.62; Meltzer, supra note 10, at 678-87; Winter, supra note 10 , at 54 .

24 Meltzer, supra note 10 , at $678-87$.

${ }^{27}$ See 24 U. CHI. L. REv. 733, 739-40 (1957).

24 371 U.S. 94, 102 (1962). 
surpasses the anticompetitive impact that the union-controlled employers exert on the product market. ${ }^{29}$ Under Mr. Justice Goldberg's standard a union's direct interest in preserving its standards in the labor market would presumably overcome any effects upon product market competition..$^{30}$

It was the element of businessman-employee competition in the labor market which complicated the antitrust decisions in Carroll v. American Fed'n of Musicians. Although the Second Circuit reaffirmed prior decisions $s^{31}$ that orchestra leaders are employers in the "club-date" field, nevertheless the court found no conspiracy between the union and member orchestra leaders absent evidence of union intent to achieve its goals through commercial restraint in the product market. ${ }^{32}$ Accordingly, the court held that the compelled acquiescence of "employer-orchestra leaders" in union by-laws was not violative of the Sherman Act. Having thus disposed of the alleged union-employer conspiracy, the Court of Appeals then interpreted Mr. Justice White's opinion in Jewel Tea as asserting that any mandatory subject of collective bargaining was immune from the strictures of the Sherman Act. ${ }^{38}$ Allying this interpretation with Mr. Justice Goldberg's "union interest" concept, the court arrived at an obfuscated view of Jewel Tea: seemingly, matters of direct union interest above and beyond those which are mandatory subjects of bargaining are sufficient to permit the invocation of labor's exemption from antitrust liability. In deciding the price-fixing issue, the Second Circuit first rejected the local's alleged interest in controlling prices because they are the source of employee wages. Such union price-determination, stated the court, invades the "proper function of management" and distorts the balance between the antitrust and the labor laws. ${ }^{34}$ Rejecting the union's additional

\footnotetext{
${ }^{28}$ See Local 189, Amalgamated Meat Cutters v. Jewel Tea Co., 381 U.S. 676, 689-91 (1965); Cox, Labor and the Antitrust Laws: Pennington and Jewel Tea, 46 B.U.L. REV. 317, 326-27 (1966); Meltzer, supra note 10, at 718-20, 724-27, 732-34. See also Cox, Labor and the Antitrust Laws, 104 U. PA. L. REv. 252, $267-70$ (1955); Winter, supra note 10, at 54 .

${ }^{30}$ See 381 U.S. at 727-29 (Goldberg, J., concurring).

${ }^{31}$ Carroll v. Associated Musicians, 206 F. Supp. 462, 476 (S.D.N.Y. 1962), aff'd, 316 F.2d 574 (2d Cir. 1963); Cutler v. American Fed'n of Musicians, 211 F. Supp. 433, 446 (S..D.N.Y. 1962), aff'd, 316 F.2d 546 (2d Cir.), cert. denied, 375 U.S. 941 (1963).

32372 F.2d at 164 . See generally Turner, The Definition of Agreement Under the Sherman Act: Conscious Parallelism and Refusals to Deal, 75 Harv. L. Rev. 655 (1962). ss 372 F.2d at 165 .

34 Ibid.
} 
argument that price-fixing was "essential to the mandatory subject of job protection," the court noted that wages saved through employerperformed work might well provide the orchestra leader a competitive edge in the market, resulting in more, not less, work for union employees. ${ }^{35}$ Furthermore, an employer's choice to perform work otherwise claimable by an employee is not a mandatory subject of collective bargaining. ${ }^{30}$ Thus, the Second Circuit determined that price-fixing was not justified on either of the criteria derived from Jewel Tea.

Simultaneously, the coerced unionization of performing orchestra leaders was exempted from the prohibitions of the antitrust laws as a legitimate effort to achieve a closed shop. ${ }^{37}$ While the court did not, and obviously could not, hold that the closed shop was a mandatory subject of collective bargaining under the NLRA, ${ }^{38}$ it did rule that the closed shop was a matter of "legitimate union concern" as a "term or condition of employment."39 Apparently subsuming the closed shop without the broader and permissible mandatory subject of union security, the court determined that Carroll was not a case where the employers "do not present job threats to union members."40 Thus the orchestra leader's employee status in the steady and "non-club" date fields, as well as the interchange of employer-employee roles in the "club-date" market itself, led the court to conclude that "every time a non-union orchestra leader performs, he displaces a 'union job' with a 'non-union job.' "41 The compelled organization of employers was therefore permissible to achieve uniform labor standards-a matter of direct union interest.

This remedy of the Second Circuit is ultimately ineffectual as

as Id. at 166.

${ }^{80}$ Ibid. But cf. Local 24, Teamsters Union v. Oliver, 358 U.S. 283, 293-95 (1959).

37372 F.2d at 167-68.

${ }^{88}$ See NLRB v. General Motors Corp., 373 U.S. 734, 740-42 (1963); NLRB v. Local 996, Teamsters Union, 313 F.2d 655, 663 (9th Cir. 1963); National Labor Relations Act, $\$ 8$ (a) (3), added by 61 Stat. 140 (1947), 29 U.S.C. $\$ 158$ (a) (3) (1964) (outlaws the closed shop). See generally 1 NLRB, Legrslative History of the Labor Management RELATIONS Acr, 1947, at 545, 612, 867 (1948); 2 id. at 1596-97.

${ }^{80} 372$ F.2d at 167. Compare Kolb v. Pacific Maritime Ass'n, 141 F. Supp. 264 (N.D. Cal. 1956). See generally Winter, supra note 10.

10 See 372 F.2d at 168. See also United States v. American Fed'n of Musicians', 47 F. Supp. 304 (N.D. Ill. 1942), aff'd per curiam, 318 U.S. 741 (1943). See generally Local 24, Teamsters Union v. Oliver, 358 U.S. 283, 293-95 (1959). 1372 F.2d at 168. 
well as anomalous for it prohibits union-imposed price schedules while allowing the local to prevent non-union employers from entering the market as performing orchestra leaders. Such an empty result might well have been avoided by discarding the bifurcated Jewel Tea test in favor of a sui generis approach as advocated by the dissenting judge. ${ }^{42}$ The "club-date" market emphasized in Carroll presents an unusual situation: not only does the union maintain a virtual closed shop of performing employers, but the possibility of meaningful collective bargaining is minimized by both the transitory nature of employment and the frequent interchange of roles between employer and employee. Since the union excludes the noncomplying performer from the market, the effect of this employer closed shop is to eliminate price competition, thereby depriving the public of lower music costs. However, the elimination of price-fixing does not dissipate the union's ultimately anticompetitive control over orchestra leaders. The entire scheme must be evaluated. Accordingly, the antitrust consequences of this arrangement depend on whether union control over the performing orchestra leader and the rates he charges is necessary to the protection of union work and wages. ${ }^{43}$ That inquiry is predicated upon the existence of job competition between the employer and employee.14 There is no competition regarding the employer's choice to fulfill all aspects of his role, including that of conducting the orchestra. Consequently, he presents no threat to union musicians: he does not displace musicians but rather creates jobs for them. Therefore, contrary to the decision of the Second Circuit, the union should not be permitted to impose any of its controls on the performing orchestra leader when he functions in that capacity. A leader free from such restrictions would present a competitive alternative in a union-dominated market and would also provide a potential partner for effective collective bargaining. ${ }^{45}$ However, since the performing orchestra leader often works as a sideman, union membership and regulation of his employee activities would also appear to be appropriate. Yet such a dichotomization for the purpose of delineating the sphere of union control assumes that a labor organization can

\footnotetext{
12 Id. at 169-70 (Friendly, J., dissenting).

4 Compare Local 24, Teamsters Union v. Oliver, 358 U.S. 288, 298-95 (1959), with Los Angeles Meat Drivers Union v. United States, 371 U.S. 94, 98-103 (1962).

"Id. at 98; see Local 24, Teamsters Union v. Oliver, supra note 43, at 293.94.

45 See 24 U. CHr. L. Rev. 738, 739-40 (1957).
} 
simultaneously be both an effective agent as well as a bargaining opponent of its own members. The unrealistic nature of this hypothesis may account for the Second Circuit's failure to find an antitrust violation in any union conduct other than the pricefixing. However, only such a circumscription of the union's power properly reflects a reconciliation of the antitrust laws with the legitimate labor pursuits of the Musicians Union. 